\title{
CONTRIBUTIONS TO A HISTORY OF GEMOLOGY: SPECIFIC GRAVITY- ORIGINS AND DEVELOPMENT OF THE HYDROSTATIC METHOD
}

By John Sinkankas

The development of the hydrostatic method of specific gravity determination as applied to gems is traced from Archimedes's discovery to the present, with brief historical remarks supplied on other methods. This is the first in a series of articles on the history of gemology that will appear periodically in Gems \& Gemology.

\section{ABOUT THE AUTHOR}

Dr. Sinkankas is the author of numerous books and articles on lapidary work, mineralogy, occurrences of gemstones, and prospecting and collecting. With his wife, Marjorie, he operates Peri Lithon Books, in San Diego, CA, a mail-order antiquarian book business devoted to the earth sciences and related fields.

C1986 Gemological Institute of America
$\Gamma$ he first useful method of comparing the densities of substances as an aid to identification is attributed by Vitruvius (ca. 13 B.C.) to Archimedes, the famous Greek scientist (ca. 287-212 B.C.). As the story goes, Archimedes was asked by King Hieron II of Syracuse to determine if a newly delivered crown was pure gold as claimed by its maker. Archimedes received the inspiration for his now-famous displacement method of determining comparative densities when he stepped into a brimming bath tub and noted the overflow caused by the added volume of his body. Inspiration struck-Eureka! - the water displaced must be equal to the volume of any material inserted into it, and hence it must follow that for substances of equal weight, a "lighter" or less dense substance would displace more water than a "heavier" or denser material. A comparative volumetric displacement test of the crown and a mass of pure gold equal to it in weight showed that the crown displaced more water, hence it had to be "lighter," hence it had to be adulterated. This fundamental principle first enunciated by Archimedes is basically the one that we still follow in all measurements of specific gravity involving immersions in fluid. Incidentally, the scoundrelly goldsmith was executed.

Although little progress was made in the hydrostatic measurement of specific gravity during more than 10 centuries following Archimedes's discovery, the increased interest in gemstones from the late 17 th century on led to fairly rapid developments both of the method and of specific values from that time. Today, the hydrostatic technique for measuring specific gravity is a standard test in gemstone identification (see box). The following discussion traces the origins and development of this very basic gemological tool.

\section{EARLY DENSITY TESTS OF PRECIOUS METALS}

Differences in weight among objects of equal size were appreciated in Roman times according to Ball (1950), who 


\section{THE HYDROSTATIC METHOD OF DETERMINING SPECIFIC GRAVITY}

The Archimedes principle states that an object immersed in water displaces a volume of water equal to its own. Thus, when Archimedes stepped into his bath, the water level rose. In addition, however, the water (or any liquid, for that matter) exerts a buoyant force upwards on the immersed object, against the downward force of gravity, and the object appears to have lost weight in comparison with its weight in air. This loss of weight is the same as the weight of an equal volume of water (the amount displaced, in fact).

The hydrostatic method of determining specific gravity depends on these simple laws of physics. First, one weighs the gemstone in the normal manner on an accurate balance. Since specific gravity is a ratio, any unit of measure (carats, grams, etc.) will do. The balance is then set up with a special apparatus such as that shown in figure 1. The stone is placed in the wire basket suspended in the container of water and its new weight can then be measured.

The numeric value for specific gravity is the ratio of an object's weight in air to that of an equal volume of water, which can be found by the formula:

$$
\frac{\text { wt. in air }}{\text { i. (wt. in air) - (wt. in water) }}
$$

The term density is often used interchangeably with specific gravity but, while the numeric values derived for each are nearly the same, the former is actually the mass per unit volume of a substance and is expressed in grams per cubic centimeter $\left(\mathrm{g} / \mathrm{cm}^{3}\right)$. Specific gravity - a ratio-has no unit.

summarized the gemological content of Pliny's Natural History of 79 A.D. Ball noted early knowledge concerning the heaviness of placer gold and that the ancient miners took advantage of this property to separate the gold from lighter rock particles. Pliny himself was aware of differences in weight among lighter objects, such as precious stones, for as Ball states, "Pliny's first test for differentiating genuine precious stones from glass imitations is weight, for ordinarily the genuine stone is heavier than the false." Egyptian records indicate that even before Pliny's time the heaviness of gold was well known and used in concentration operations during gold mining (Forbes, 1950). Davies (1809) refers to the work De Ponderibus et Mensuribus (Weighing and Mensuration), written approximately 45 A.D. by Quintus Remnius Palaemon, which showed how specific gravities of solids could be ascertained.

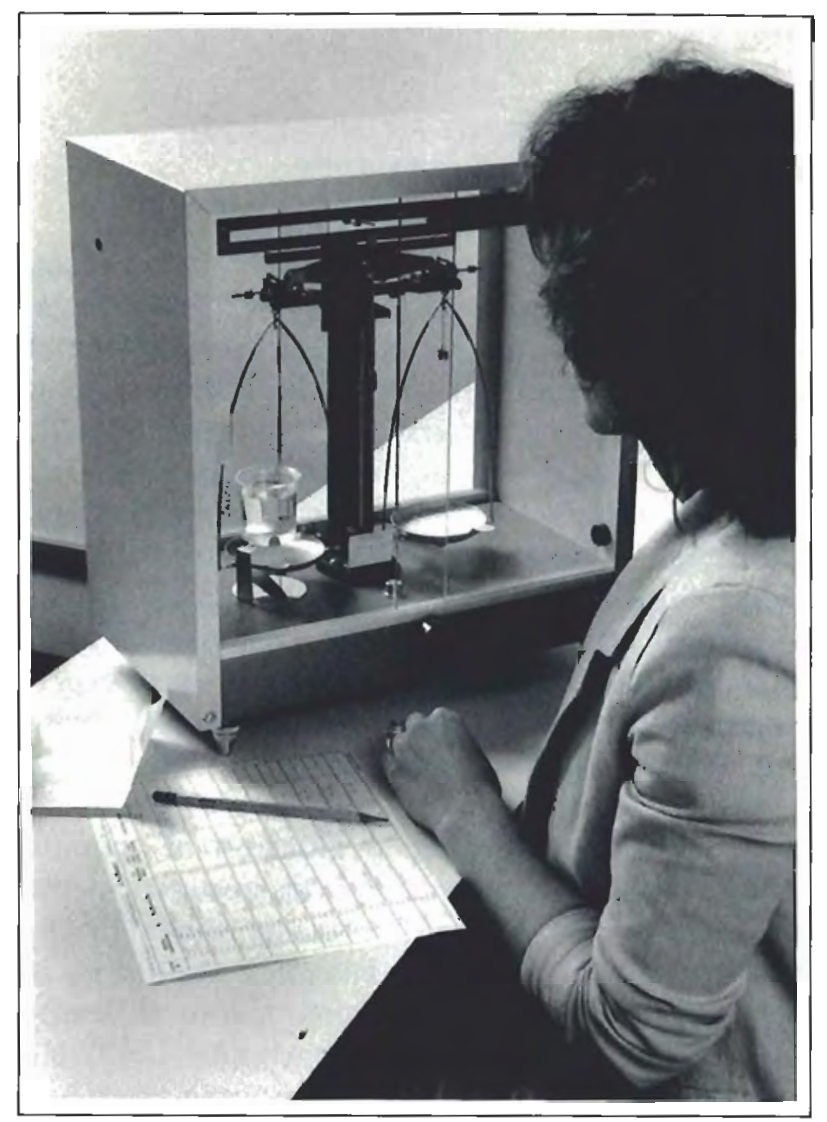

Figure 1. A contemporary balance used for the

hydrostatic determination of specific gravity.

The use of precious metals as marks of wealth and, more importantly, as media of exchange in commerce, early established a need for standardizing the proportions of gold and silver (the principal alloying metal) in coins and in other applications. According to Smith and Forbes (1957), crude means of specific-gravity determination were developed as early as the sixth century when "a balance with a graduated beam and movable fulcrum was described in the poem Carmen de Ponderibus (Poem on Weighing) attributed to Priscian." They further note that as early as the 11 th and 12 th centuries a list of weights of metals relative to wax was compiled for the purpose of assisting a foundryman to determine how much metal to melt. "By the seventeenth century extensive tables of similar [specific gravity] data became common in mathematicians' works." A table devised particularly to help the assayer appeared in the 13th century, and by the close of the 16th century, not only were the principles understood but man's ingenuity was also being turned to the design and manufacture of more precise balances. 


\section{SEVENTEENTH- AND EIGHTEENTH- CENTURY EUROPE: DENSITY TESTING OF GEMSTONES BEGINS}

A notable experimentalist was Francis Bacon (1561-1626), who drew up a table of densities, published some time after his death, which Davies (1809, p. 537) believed to be "the oldest table of specific gravities now extant." Davies also cited an even earlier contribution, that of Marinus Ghetaldus (1566-1626), who made his own hydrostatic experiments "with care and exactness," and in 1603 published a treatise on weighing. Ghetaldus is credited with determining the first specific gravity for any metal (Debus, 1968). Other early experimentalists include Johannes Baptista Villalpandus $(1552-1608)$ and Marin Mersenne (1588-1648).

Possibly because the evaluation of specific gravity of gemstones was of little concern in the early 1600s, we find that Boetius de Boodt (15501634), who may justifiably be called the "Pliny of Gemology," says nothing more about differing gemstone densities than that they exist (1647). He gives no hint that any method of placing a numerical value on this property existed among gem dealers and jewelers of the time. It is, of course, possible that because gems are usually very small relative to other materials, existing apparatus could not be counted on to afford consistent, reliable results. In contrast, chemists and physicists of the same period were actively measuring densities, devising better methods and instrumentation, and defining the limitations of the hydrostatic method. For example, Robert Boyle (16271691), best known among gemologists for his Essay about the Origine and Virtues of Gems (1672), produced a treatise in 1666 titled $H y$ drostatical Paradoxes Proved and Illustrated by Experiments (Boyle, ed. by Shaw, 1725).

Boyle tested a variety of substances, including gem materials, with the balance shown in figure 2, but preceded his remarks with advice on how to go about obtaining the greatest accuracy. First, he describes the balance and its parts and accessories. He then states that he found horse hair to be the best suspension thread because "its weight usually differs so little from that of water, that the difference may be safely neglected." However, he advises that an equal quantity of hair ${ }_{\eta \prime}$ as was used to fasten the specimen for immersion weighing, be placed in the opposite pan to reduce error. Other instructions for specific-gravity weighings are

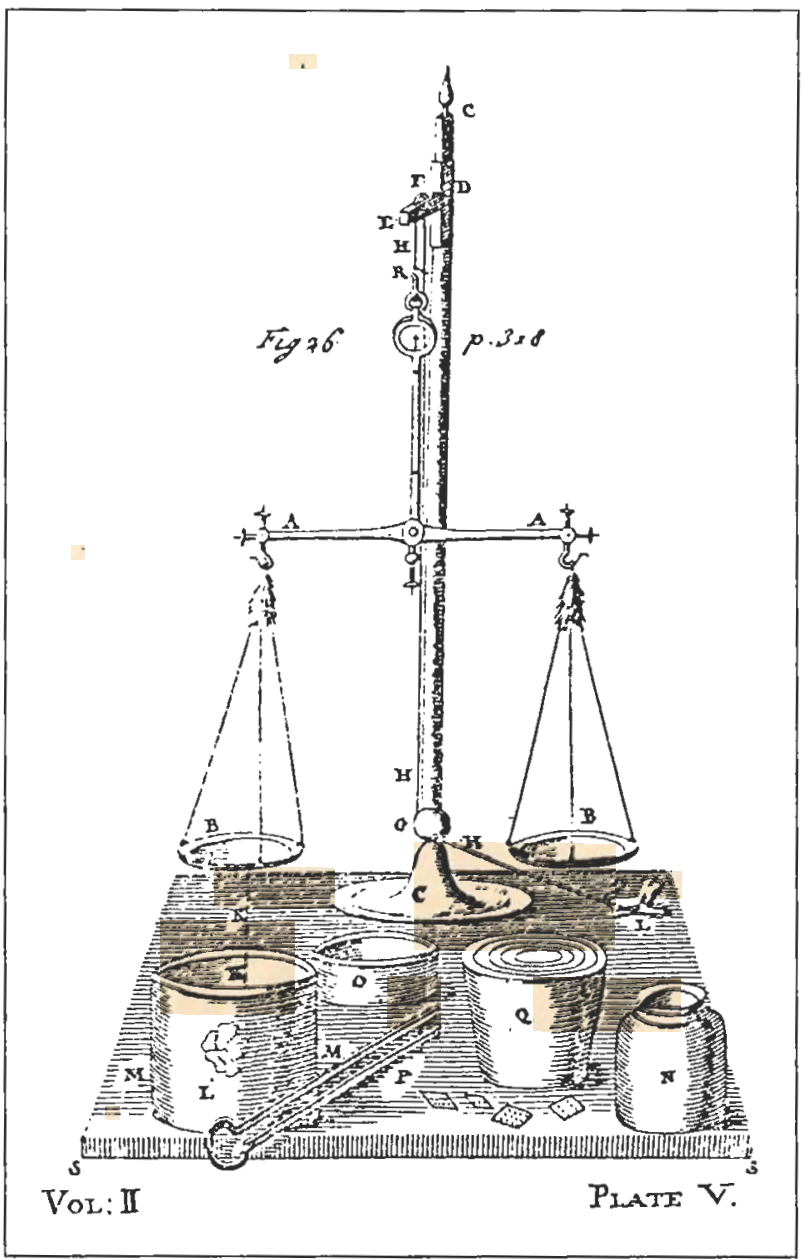

Figure 2. Plate $V$ from the second volume of Robert Boyle's collected works (P. Shaw edition of 1725) showing his specific-gravity balance and associated accessories. The principal parts are the stand $\mathrm{C}-\mathrm{C}$ and the rather elaborate means for raising and lowering the beam A-A and pans B-B with pulleys and weight (the small lion on the right, erroneously marked $\mathrm{L}$ ). The specimen $\mathrm{L}$ (on the lower left) is shown suspended by horsehair $\mathrm{K}$ in the water bucket M-M. Grain weights are in container $\mathrm{O}$, larger weights (nested) are in $\mathrm{Q}$, jar $\mathrm{N}$ holds the water supply, and the forceps Pare used to handle weights.

equally as informative, for example, avoiding bubbles, and the like, such that one cannot help but admire his thoroughness.

Boyle stressed the value of S.G. determinations in the detection of frauds and substitutes because they "may assist us to guess, with probability, whether a mineral body be of a stoney nature, or not." He was referring specifically to 
speculations at the time as to the exact nature of coral, which some thought to be a petrification and others some sort of plant. Boyle tested a fine specimen of red coral and obtained an S.G. of 2.68; he noted that this value "exceeded that of crystal [quartz]," and concluded that "their opinion, who take it for a stone, seems most probable." The animal nature of coral was not established until about 1723 (by J. A. Peyssonel, 1694-1759; see Lacaze-Duthiers, 1864). In connection with coral, and to emphasize the usefulness of S.G. determinations, Boyle manufactured some realistic coral imitations and then showed how these were easily detected on the basis of S.G. "notwithstanding their fine colour, shape, and gloss." Other tests were made on preparations of "pastes or factitious gems," made with red lead (minium), which again were easily distinguished on the basis of their specific gravities.

With regard to pearls, which he also tested, Boyle makes the significant remark that specificgravity weighings are nondestructive in nature, and "a pearl, for instance, is discoverable to be counterfeit, 'without the least prejudice to it." On one "monsstrous" (206 grains) baroque pearl, he determined a specific gravity of 2.51 . Because of his interest in disclosing the frauds then prevalent in medicine, Boyle included in his tests the enormously expensive bezoars and other calculi to show that these organic materials, whatever their medicinal values, could be readily distinguished from mineral concretions of like appearance. At the end of his discourse, Boyle provided the results of his tests in the form of tables which are reproduced here as figure 3 ; note that some gemstones are included.

Also during the first half of the 18th century, John Ellicott \{?1706-1772\}, noted instrument maker and scientist, very precisely determined the specific gravity of a series of 14 large diamonds, four from Brazil and 10 from the "East Indies" (Borneo?). The stones included some that were in excess of 29 ct (Davies, 1809). It was the size of the stones that inspired Ellicott to undertake the determinations, because hitherto most test specimens had been only a few carats or less. Ellicott's values, $3.501-3.525$, average 3.517 , compare fa-

Figure 3. Robert Boyle's tables of specific-gravity values obtained through the use of the apparatus shown in figure 2 (from the P. Shaw edition of 1725).

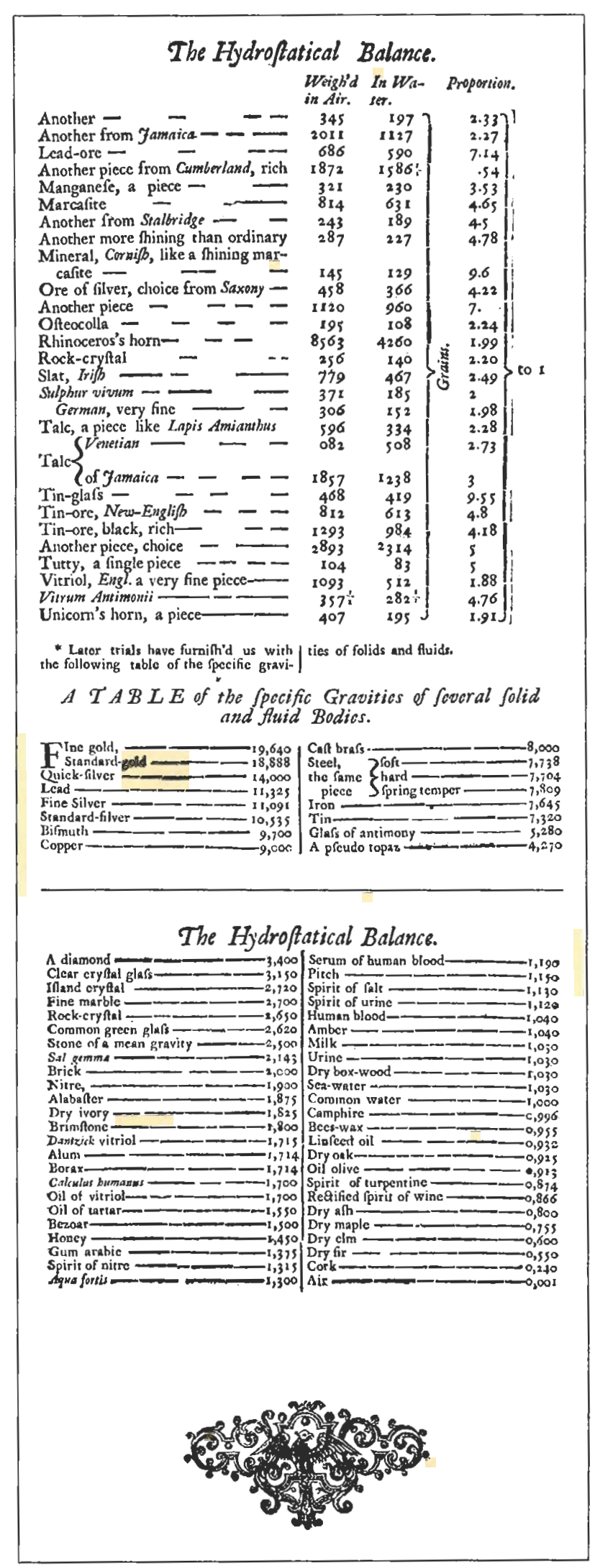




\section{PESA N T E U R $S P E ́ C I F I Q U E$. DE S C OR P S.}

Ouvrage utile à l'Hifoire Naturelle, à la Phyfique, aux Arts \& au Commerce.

Par MT. BRISsON, de I'Acadimie Royale des Sciences, Miaire de Pliyfique of d'Hifloire Naturelle des Enfans de France, Profefeur Royal de Pliyfique Expérimentale au Collige Rojal de Navarre is Cenfeur Royal.

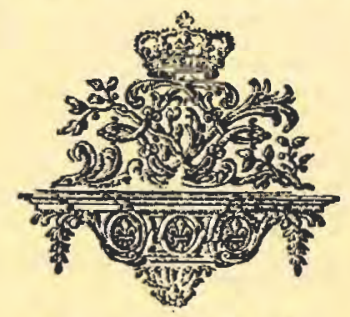

A P A R I S,

DE LIM PR I MER I E ROYALE.

M. DC C LXXXVII.

Figure 4. Title page of Brisson's 1787 work on specific gravity.

vorably with today's generally accepted range of 3.514-3.518 (Bruton, 1978).

Great interest was aroused throughout Europe by the density information that the hydrostatic method could provide for many substances, as shown in the lengthy article and extensive tables of Richard Davies, M.D. (d. 1768), originally published in the Philosophical Transactions of the Royal Society of London (Vol. 45, No. 488, 1748, pp. 416-489) and republished in abridged form (Davies, 1809). Davies provided an excellent historical summary, including a survey of investigators and their methods and findings, beginning with Archimedes. He then incorporated the findings of Ghetaldus, Villalpandus, Mersenne, Boyle and others into 11 tables, each with numerous entries and citing sources for same; three of these tables $\{1,3$, and 4$\}$ contain data on gem materials. The 11 th table provides adjustments to be applied to specific gravities according to season, summer to winter, which serve as a crude set of temperature corrections.

In 1798, Charles Francis Greville (1749-1809) published an extensive description of the corundums of Asia, which also appeared in abridged form (Davies, 1809, Vol. 18, pp. 356-378). He provided S.G. tables for a number of varieties of corundum, as reported by earlier researchers, as well as values for topaz and diamond.

Among the most important specific gravities incorporated in Davies's tables are those of P. van Musschenbroek (1692-1761), the celebrated Dutch scientist, which were first published in his Elementa Physicae (1734) and republished, enlarged, in his Essai de Physique (1739). These values were consulted by $M$. J. Brisson (17231806), the famous French physicist, during his compilation of Pesanteur Spécifique des Corps (Specific Gravities of Bodies). Published in 1787, this is clearly the most accurate and complete of all specific-gravity compilations of that period (figure 4). A German translation by J. G. L. Blumhof, with some rearrangement and augmentation, was published in Leipzig in 1795 . Both works are rare, which may account for their neglect by most gemological historians; only B. W. Anderson (1938) notes Brisson's original treatise and provides a thoroughly detailed and admirable analysis. Brisson explains his methods, his apparatus, his standard use of rainwater as an immersion fluid, and the adoption of a standard temperature for measurements. As a result of his care, his values are in most instances remarkably close to those considered acceptable today. Brisson recognized that specific-gravity values tend to be constant for minerals and urged that these values be used in conjunction with obvious external features-especially crystal forms (of which he provided two engraved plates), and also color, hardness, and the phenomenon of double refractionto identify gemstones in particular, thus setting forth the first scientific proposal for gemstone identification. His scheme precedes even that used by Haüy in his epochal gemological treatise (1817), which will be described below. Brisson was remarkably thorough in obtaining specimens to test, including gemstones; scarcely any known at the time failed to catch his attention. By exercising his prestige and position, he obtained the loan of the Regent diamond from the French Crown Treasury and was the first to establish its specific gravity. 
By the end of the 18th century, the usefulness of the hydrostatic method was everywhere acknowledged and specific-gravity values had become routine data in numerous chemical and physical treatises. Among gemological textbooks, for example, which also incorporated such data, that of C. Prosper Brard (1788-1838), Traité des Pierres Precieuses (1808), provided a list of gemstone specific gravities, in descending order, from zircon to amber, and a list of weights per cubic foot of various ornamental and building stones. Shortly afterward, in 1813, J. B. Pujoulx (1762-1821) published an economic mineralogy which stressed the importance of correlating property values and features in gem identification, and described the structure and use of the Nicholson hydrometer for taking specific gravities.

\section{THE NINETEENTH CENTURY: SPECIFIC GRA VITY ASSUMES A KEY ROLE IN GEM IDENTIFICATION}

In 1817, a large and detailed discussion of specific gravity and its importance in mineralogical identification appeared in the Propadeutik der Mineralogie of C. C. Leonhard, J. H. Kopp, and C. L. Gaertner, which also provided a history of previous investigations as well as a large table of specific-gravity values ranging from several substances less dense than water to gold. Another important table provided temperature corrections for weighings in water. This year also marked the appearance of R. J. Haüy's landmark work, Traite des Caractères Physiques des Pierres Précieuses (Treatise on the Physical Characteristics of Precious Stones).

While the fundamental concept of correlating several properties or features to achieve identification had already been clearly enunciated by Brisson, with whose work Haüy was familiar, it was left to the latter to write the first usable textbook, per se, of gem identification in which the reader is told what all the properties are, why they are characteristic, and how they may be measured, tested, or observed. This general discussion is followed by 11 tables that are surely the first of their kind as applied to gemstones and the model for many others published since. The first argument is color, hence the tables are headed colorless, red, blue, green, etc., with a "red-brown" table for zircons, another for gems displaying reflecting phenomena such as asterism and adularescence, and a final table for opaque gems of blue-green color, that is, real turquoise and "bone turquoise." Color as a first argument remains very much in use today, for example, in B. W. Anderson's Gem Testing (1980). Within each table, Haüy gives columns for light phenomena, specific gravity, hardness, single or double refraction, electrification by friction, same by heat, and magnetism /undoubtedly his inclusion of electrical/magnetic properties was inspired by his investigations of these phenomena at about the time that he became interested in gemstones). The importance of Haüy's treatise was immediately recognized and led to a German edition (1818) and an Italian edition (1819). In 1825, Haüy issued a pamphlet summary of the main work with a series of crystal drawings.

In 1832, two important gemological texts appeared with significant information on specific gravity: the first, a small "pocketbook" by J. R. Blum (1802-1883); the second, a much more detailed work by P. Boué. Blum provided an extensive table of color versus specific gravity that in part followed Haüy's scheme. Boué's work devoted more space to specific gravity and incorporated an engraved plate that depicted a balance with a sliding weight on the arm (figure 5), which design Boué claimed was invented by Brard, although the latter said nothing about it in his 1808 book. An important novelty of Boue's treatise is his inspection table for specific gravity (Vol. 2, plate 3).

The first book after Brisson (1787) to devote itself solely to the specific gravity of mineral substances was M. Websky's 1868 work, which coupled specific gravities with increasing hardness in a series of ranges from S.G. $0.4-0.7$ to S.G. 12-25. While gemstone species are included, they are not specifically designated nor are they treated separately. Subsequent gemological treatises have included S.G. data. The most extensive S.G. table for minerals and gemstones currently available is in the Gemstone and Mineral Data Book (Sinkankas, 1972).

\section{OTHER METHODS OF DETERMINING SPECIFIC GRAVITY}

Although no attempt has been made in this contribution to discuss other methods of determining specific gravity, a few notes on them may be of interest to place the hydrostatic method in perspective. The pycnometer, or specific-gravity bottle, is sometimes used in gemological determinations. This special glass flask is first filled with water, then weighed; next the flask is emptied and 


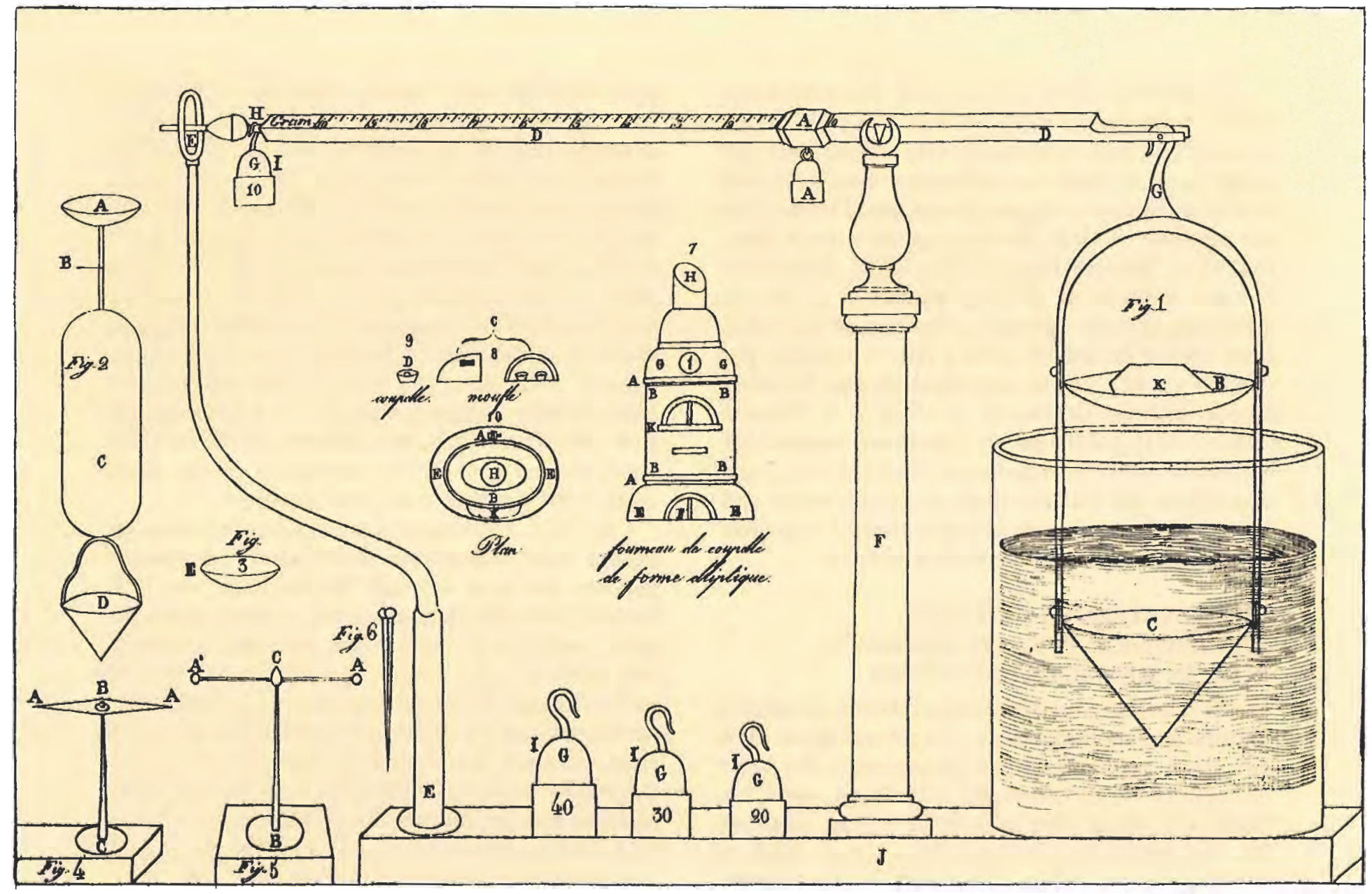

Figure 5. Plate 3 from Boue's treatise on jewelry showing a sliding weight beam balance ("Fig. 1") with pans for weighing in air and weighing in water. When the specimen $\mathrm{K}$ is placed in the upper pan, one of the weights marked Gis selected to balance the beam, and the slider A is adjusted to give the final balance. When the specimen is placed in the lower pan $\mathrm{C}$, the difference between the slider positions gives loss of weight in water.

the gem fragment or cut gem inserted; last, the bottle is refilled with water and weighed again. The displacement of water by the gem material measures gem volume and hence enables the specific gravity to be determined. There are various forms of pycnometer bottles, a common type being that shown in figure 6 . According to Darmstaedter (1908), the first pycnometer can be traced to 1121 A.D. and a certain Arabian savant, named Alkhazini, who investigated the specific gravity of fluids. The modern form of the pycnometer was devised in 1699 by chemist Wilhelm Homberg (1652-1715).

The simple yet effective hydrometer invented by the ingenious English instrument maker, William Nicholson (1753-1815), around 1787 was greeted everywhere with enthusiasm due more to its ease of operation than to any increase in accuracy. It also suffered from severe capacity restrictions which required, in the case of cut-gem weighings, that a series of instruments be manufactured to accommodate different sample weights. A typical Nicholson hydrometer is shown in figure 7 . The crucial place on the instrument is the slender neck between the upper pan and the large hollow body, because it is along this neck, suitably graduated, that the difference is noted between a weighing with the gem in the upper pan (weight in air) and in the lower pan (weight in water). Ordinary glass hydrometers can be modified to become crude Nicholson instruments, if one chooses to experiment with this device.

Another S.G. instrument, again inspired more 
by the need for quick determinations than for accuracy, is the Jolly balance shown in figure 8. It is named after its inventor, P. J. G. von Jolly (1809-1884), and depends for its operation on the extensibility of a tapered spring of many turns from which hangs a double-pan arrangement; the upper pan is for in-air weighings and the lower one, immersed in water, for in-water weighings. Differences in weight are indicated by a pointer attached to the spring which moves against the vertical scale on the same column that supports the spring. Even today, the Jolly balance is used much more frequently than either the beam balance or the Nicholson hydrometer; the latter is actually now an antique of considerable collection value.

The influence of liquids of densities higher for lower) than water on the flotation of solids must surely have been apparent to man at some very distant age in the past, but only in relatively recent times was it deemed feasible to use heavy liquids as indicators of the specific gravity of the solids immersed in them. While a simple "sink or float" test was indicative, it was also found that certain liquids could be diluted to provide an entire range of knownidensities, so that a precise determination on a given sample became possible. A good

Figure 6. A pycnometer, or stoppered glass bottle, for determining specific gravity. From Groth (1887).

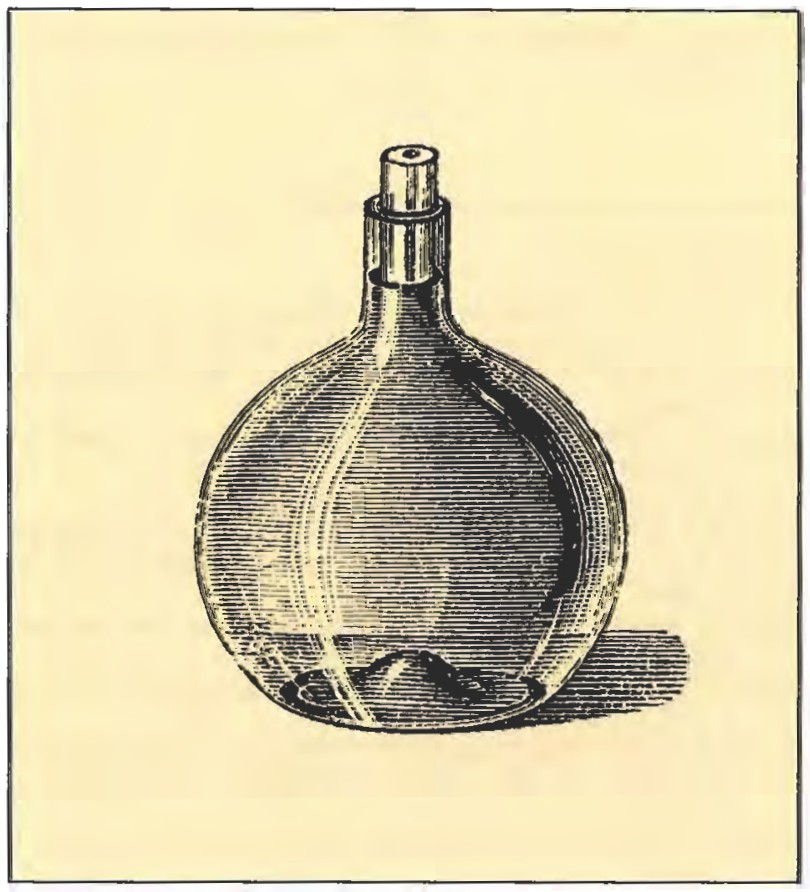

summary of the problem, investigators, instrumentation, etc., appears in Thorpe (1913). Thorpe claims that the first use of heavy liquids for S.G. determination can be dated to 1862, but the first liquid generally adopted for the purpose is

Figure 7. Nicholson's hydrometer. Upper pan F-K is for "in-air" weighing, readings are taken from graduated stem b, O-S is the boyancy float, and $\mathrm{E}-\mathrm{G}$, the lower pan, is for "in-water" weighing. Not shown: glass cylinder in which apparatus floats in water. From Kobell (1864, p. 115).

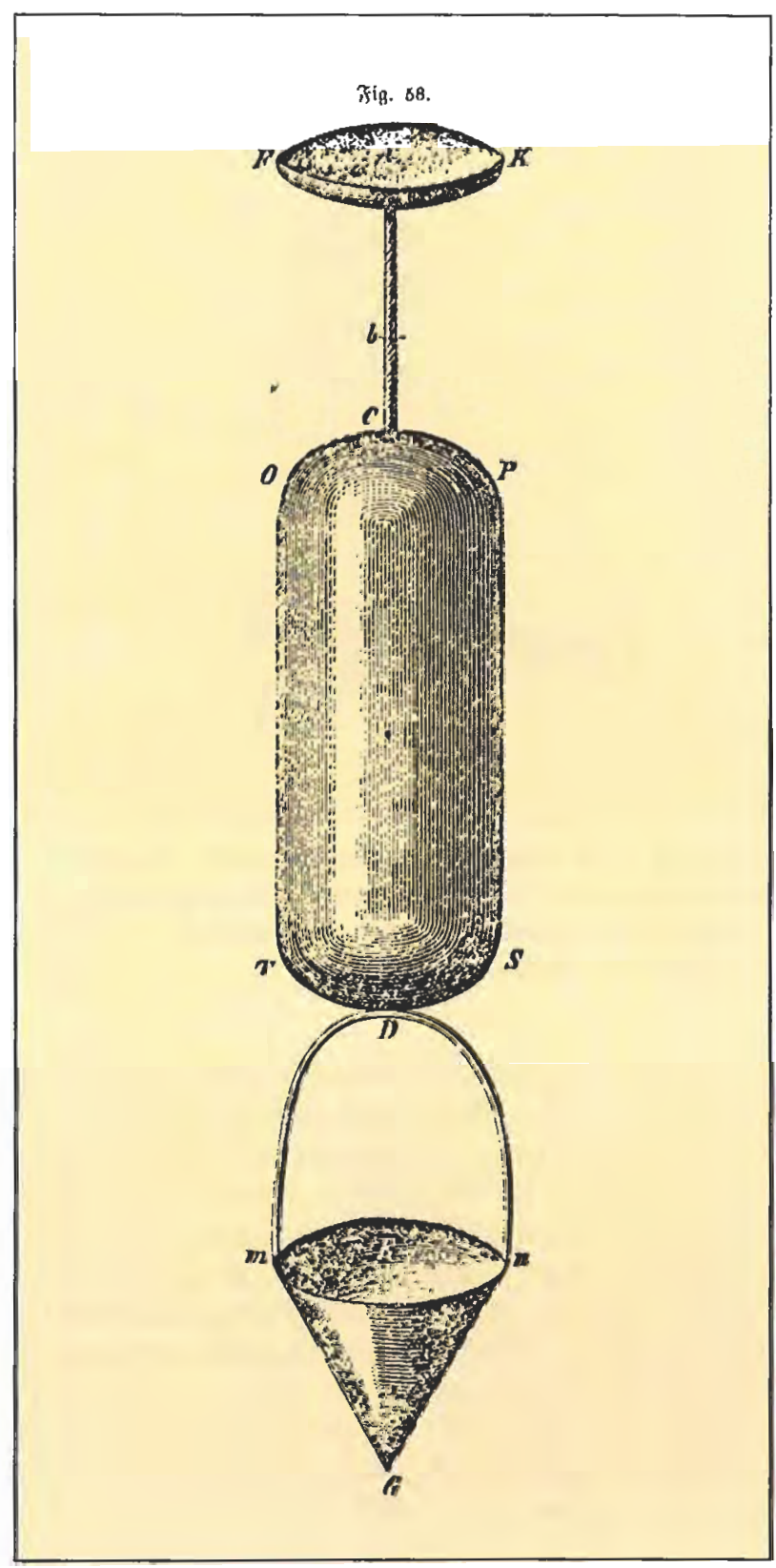




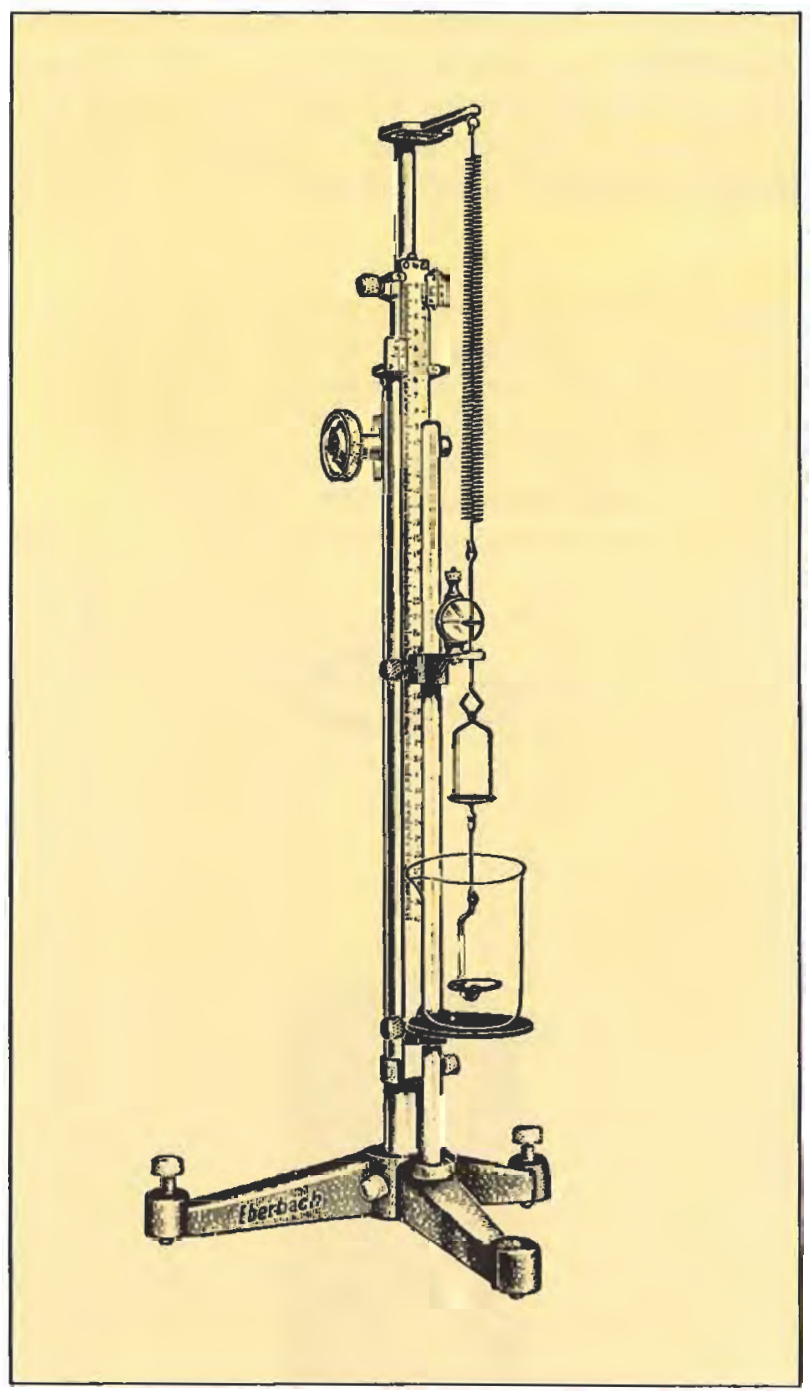

Figure 8. Jolly balance, still much used for rough determinations of specific gravity of large gems or mineral specimens. Courtesy of Eberbach Corporation, Ann Arbor, MI.

Sonstadt's or Thoulet's solution, first proposed by Sonstadt in 1874. The usefulness and convenience of a number of heavy liquids is counterbalanced by their noxious or even actively poisonous properties. However, the discovery of methylene iodide, a relatively safe compound, and its use in petrography (Brauns, 1886) led also to its adoption for testing gems. The first gemological textbook to incorporate instructions on the use of heavy liquids was that of P. Groth (1887). Much more elaborate instructions then appeared in Max Bauer's classic text, Edelsteinkunde (1st edit., 1896). In the course of time, other liquids besides those mentioned above have been developed and are still used in relative safety for the immersion method of gem testing.

For a valuable review of the problems associated with suspension separation of minerals in heavy liquids, including a large number of abstracts of pertinent literature, see P. G. H. Boswell (1933) and also the large paper by J. D. Sullivan (1927). A fascinating account of weighing and the use of scales and weights throughout the ages is contained in B. Kisch (1965).

Lastly, it should be mentioned that various instruments have been devised to measure the volume of water displaced by a solid. A very obvious and simple method is to place a specimen in a graduated cylinder filled to a certain mark with water, and then to note the apparent increase in water volume which, of course, gives the volume of the immersed object.

\section{CONCLUSION}

The hydrostatic method of S.G. determination, now more than 2,000 years old, is still an excellent method for obtaining rapid results without the need for possibly dangerous test substances. However, its accuracy drops sharply when small specimens or cut gems are used, and for the latter immersion fluids may prove to be faster and more convenient. For extremely accurate determinations, many investigators still employ some form of pycnometer under carefully controlled conditions in conjunction with a very precise analytical balance.

\section{REFERENCES}

Anderson B.W. (1938) Brisson's "Pesanteur Spécifique des Corps." Gemmologist, Vol. 8, No. 87, pp. 36-38.

Anderson B.W. (1980) Gem Testing, 9th ed. Butterworths, London.

Ball S.H. (1950) A Roman Book of Precious Stones. Gemological Institute of America, Los Angeles, CA.

Bauer M. (1896) Edelsteinkunde. Leipzig.

Blum J.R. (1832) Taschenbuch der Edelsteinkunde. Stuttgart.

Boodt A.B. (1647) Gemmarum et Lapidum Historia, 3rd ed. Leyden.

Boswell P.G.H. (1933) On the Mineralogy of Sedimentary Rocks. Thomas Murby, London.

Boué P. (1832) Traité d'Orfevrerie, Bijouterie et Joaillerie. Vols. 1 and 2, Paris.

Boyle R. (1725) The Philosophical Works of the Honourable Robert Boyle, Esq., Vol. 2. Abridged by Peter Shaw, London.

Brard C.P. (1808) Traité des Pierres Précieuses, Vols. 1 and 2, Paris. 
Brauns R. (1886) Ueber die Verwendbarkeit des Methylenjodids bei petrographischen und optischen Untersuchungen. Neues Jahrbuch für Mineralogie, Vol. 2, pp. 72-78.

Brisson M.J. (1787) Pesanteur Specifique des Corps. Paris.

Brisson M.J. (1795) Die spezifischen Gewichte der Korper. Trans. by J.C.L. Blumhof, Leipzig.

Bruton E. (1978) Diamonds, 2nd ed. Chilton Book Co., Radnor PA.

Darmstaedter L. (1908) Handbuch zur Geschichte der Naturwissenschaften und der Technik. Julius Springer, Berlin.

Davies R. (1809) Tables of specific gravities, extracted from various authors, with some observations on the same. In The Philosophical Transactions of the Royal Society of London, Abridged, Vol. 9, pp, 536-553.

Debus A.G. ed. (1968) World Who's who in Science. A.N. Marquis Co., Chicago.

Forbes R.J. (1950) Metallurgy in Antiquity. E.J. Brill, Leiden, The Netherlands.

Groth P. (1887) Grundriss der Edelsteinkunde. Leipzig.

Haüy R.J. (1817) Traité des Caractères Physiques des Pierres Précieuses. Paris.

Haüy R.J. (1818) Ueber den Gebrauch physikalischer Kennzeichen zur Bestimmung geschnittener Edelsteine. Trans. by K.S. Leonhard, Leipzig.

Haüy R.J. (1819) Trattato dei Caratteri Fisici della Pietre Preziose. Trans. by L. Configliachi, Milan.

Haüy R.J. (1825) Distribution Technique des Pierres Précieuses, avec Leurs Caracteres Distinctifs. Vienna.

Kisch B. (1965) Scales and Weights: A Historical Outline. Yale University Press, New Haven, CT.
Kobell F. von (1864) Geschichte der Mineralogie. J.G. Cottaschen Buchhandlung, Stuttgart.

Lacaze-Duthiers H. (1864) Histoire Naturelle du Corail. J.B. Ballière, Paris.

Leonhard C.C., Kopp J.H., Gaertner C.L. (1817) Propadeutik der Mineralogie. Frankfurt Am Main.

Musschenbroek P. van (1739) Essai de Physique, Vols. 1 and 2. Trans. by P. Massuet, Leyden.

Nicholson W. (1787) Description of a new instrument for measuring the specific gravity of bodies. Memoirs of the Manchester Literary and Philosophical Society, Vol. 2.

Pujoulx J.B. (1813) Minéralogie a l'Usage des Gens du Monde. Paris.

Sinkankas J. (1972) Gemstone and Mineral Data Book. Winchester Press, New York.

Smith C.S., Forbes R.J. (1957) Metallurgy and assaying. In C. Singer et al., eds, A History of Technology, Vol. 3, Oxford University Press, New York and London.

Sonstadt E. (1874) Note on a new method of taking specific gravities, adapted for special cases. Chemical News and Journal of Physical (Industrial) Science, Vol. 29, pp. $127-128$.

Sullivan J.D. (1927) Heavy liquids for mineralogical analyses. U.S. Bureau of Mines, Technical Paper 381.

Thorpe E. (1913) A Dictionary of Applied Chemistry, Vols. $1-5$. London.

Vitruvius P.M. (ca. 13 B.C.) De Architectura.

Websky M. (1868) Die Mineral-Species nach den für das specifische Gewicht derselben ... Werthen. Breslau.

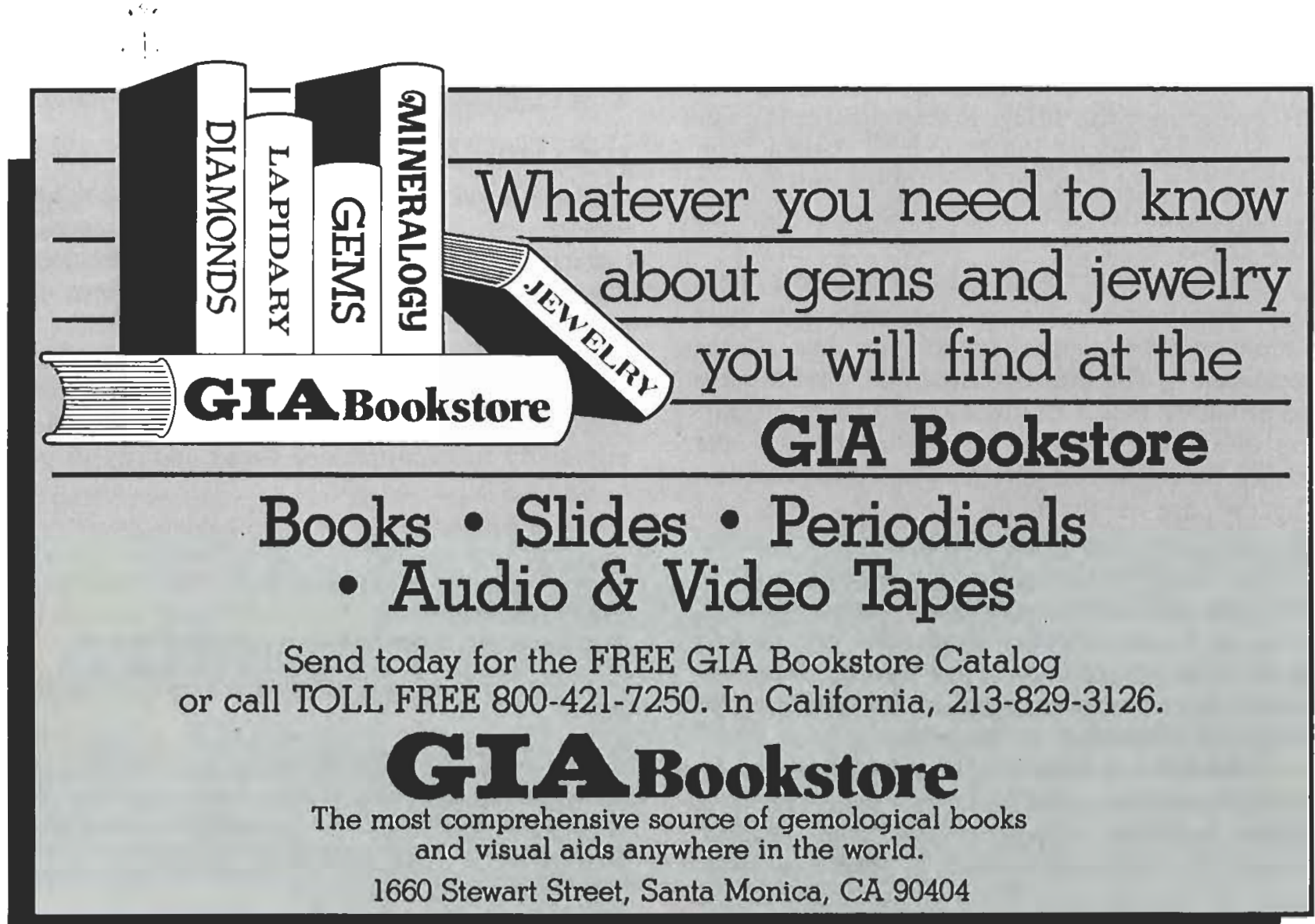

